\title{
Chapter 5 \\ The International Influence of the Emissions Trading System in Mexico
}

\author{
Alicia Gutierrez González
}

\begin{abstract}
This article aims to give an overview of the international influence of the Emissions Trading System (ETS) in Mexico. It is divided into three parts. First, it briefly examines both the international Climate Change regime through the description of such instruments as the 1997 Kyoto Protocol and the 2015 Paris Agreement, and the national regime by reviewing as the 2012 General Law on Climate Change $(L G C C)$, the National Emissions Registry (RENE) and its Regulations, as well as other instruments regarding mitigation from carbon tax and clean energy. Second, it analyzes the legal framework of the pilot phase of the ETS in Mexico (under the cap and trade principle) which seeks to reduce carbon dioxide emissions $\left(\mathrm{CO}_{2}\right)$ only in the energy and industry sectors whose emissions are greater than 100 thousand direct tonnes of $\mathrm{CO}_{2}$. In doing so, it also explains the relevance of implementing an ETS as a cost-effective mitigation measure to achieve the Nationally Determined Contributions (NDCs) in order to reduce $22 \%$ greenhouse gas (GHG) emissions by 2030 (increasing to $36 \%$ if there is international support and financing) and $50 \%$ by 2050 as a developing country. Third, it focuses on the European Union Emissions Trading System (EU ETS) experience and shows that all its phases must be done gradually by adopting the learning-by-doing approach.
\end{abstract}

Keywords Emissions trading system $\cdot$ Mexico $\cdot$ Paris agreement $\cdot$ European unión $\cdot$ Climate change

\section{International Instruments}

Environmental problems are currently the subject of international concerns (Malcolm 2014, p. 613). The question of the relationship between the protection of the environment and the need for economic development is a problem that developing countries have been dealing with due to the fact that it is very expensive for them to find a response to this in an environmentally safe way (Malcolm 2014, p. 617).

\footnotetext{
A. Gutierrez González ( $\otimes)$

Facultad de Estudios Globales de la Universidad Anáhuac México, Estado de México, México e-mail: alicia.gutierrez@anahuac.mx
} 
Currently, the international community is facing the main challenge of development with environmental protection. On the one hand, some nations invoke state sovereignty, and on the other, several countries reiterate the need for international cooperation (Malcolm 2014, p. 631). In this regard, Antonio Cassese explains that "the environment has come to be regarded as a common amenity; as an asset in the safeguarding of which all should be interested, regardless of where the environment is or may be harmed" (Cassese 2005, p. 487).

The protection of a clean and healthy environment requires international cooperation, because national actions by themselves may be insufficient (Dixon et al. 2011, p. 441), therefore, the importance of adopting and implementing international principles and rules in treaties, agreements, protocols, and so on.

At the international level, the United Nations has played an important role regarding climate change. The 1992 United Nations Framework Convention on Climate Change ${ }^{1}$ (UNFCCC) establishes under Article 2 that: "The ultimate objective of this Convention and any related legal instruments ...... is to achieve .... stabilization of greenhouse gas concentrations in the atmosphere at a level that would prevent dangerous anthropogenic interference with the climate system".

This objective shows that anthropogenic emissions are the principal danger in climate change, and therefore, the greenhouse gas concentrations must be limited, so that they can be stabilized (Dupuy and Viñuales 2018, p. 177). Regarding the UNFCCC, it sets out in Article 3 the principle of common but differentiated responsibilities (among other principles), which states that:

\section{The Parties should protect the climate system for the benefit of present and future generations of humankind, on the basis of equity and in accordance with their common but differenti- ated responsibilities and respective capabilities. Accordingly, as parties, developed countries should take the lead in combating climate change and the adverse effects thereof (Convention of Climate Change 1992).}

This principle is twofold because it states the responsibility of developed countries to take on obligations for the protection and preservation of the environment and it establishes different environmental obligations for developing countries. The ultimate objective of this Convention is to stabilize greenhouse gas emissions at a level that would prevent dangerous anthropogenic interference with the climate system (Birnie et al. 2009, p. 358). The UNFCCC entered into force on 21 March 1994. Since then, there have been other global agreements regarding protection of the atmosphere and the environment. Unfortunately, the emissions of greenhouse gases continue to rise and there is a climate emergency, which includes:

(i) frequent droughts;

(ii) floods;

(iii) storms;

(iv) earthquakes;

(v) loss of biodiversity; and so on.

\footnotetext{
${ }^{1}$ The 1992 Convention on Climate Change has been ratified by 194 States.
} 
It is worth mentioning that the principle of common but differentiated responsibilities was set out in Principle 7 of the 1992 Rio Declaration on Environment and Development adopted in the United Nations Conference on Environment and Development (Rio Declaration on Environment and Development 1992). This principle states that the countries "shall cooperate to conserve, protect and restore the health and integrity of the Earth's ecosystem". For this reason, the Rio Earth Summit had the goal of preventing dangerous human interference in the climate system. Thus, the Rio Declaration and the UNFCC show that protecting the environment requires international cooperation and that the responsibility to undertake obligations is different regarding developed and developing countries.

The international influence of the first emission trading started with the 1997 Kyoto Protocol to the United Nations Framework Convention on Climate Change (Kyoto Protocol 1997) $^{2}$ which establishes under Article 3 that:

1. The parties included in Annex 1 shall, individually or jointly, ensure that their aggregate anthropogenic carbon dioxide equivalent emissions of the greenhouse gases listed in Appendix A do not exceed their assigned amounts... with a view to reducing their overall emissions of such gases by at least 5 per cent below 1990 levels in the commitment period 2008 to 2012.

2. Each party included in Annex 1 shall, by 2005, have made demonstrable progress in achieving its commitments under this Protocol...

An achievement of this Protocol was the establishment of quantitative restrictions on emissions from developed countries. Moreover, it sets up three market mechanisms:

(i) Joint Implementation (technology development and transfer, Article 6);

(ii) The Clean Development Mechanism (implementation of measures in developing countries, Article 12) and;

(iii) The Emissions Trading (global trading in emissions rights, Article 17).

Thus, Article 6 states that:

1. For the purpose of meeting its requirements under Article 3, any Party included in Annex 1 may transfer to, or acquire from, any other such Party emission reductions units resulting from projects aimed at reducing anthropogenic emissions by sources or enhancing anthropogenic removals by greenhouse gas sinks in any sector of the economy, provided that:

(a) Any such Project has the approval of the Parties involved...

(d) The acquisition of emission reduction units shall be supplemental to domestic actions for the purposes of meeting commitments under Article 3...

3. A Party included in Annex 1 may authorize legal entities to participate, under its responsibility, in actions leading to the generation, transfer or acquisition under this Article of emission reduction units...

In the first market mechanism, i.e., the Joint Implementation, the name of the units is called the Emission Reduction Units (ERUs). The objective of the Article is to enable developed countries to undertake joint implementation projects, whereby a country can earn emission credits by investing in projects in other countries.

\footnotetext{
2 The 1997 Kyoto Protocol has been ratified by 193 Parties.
} 
In the second market mechanism as mentioned above, i.e., the Clean Development Mechanism (CDM), the units are called Certified Emission Reductions (CERs). Article 12 of the 1997 Kyoto Protocol states that:

3. Under the clean development mechanism

(a) Parties not included in Annex 1 will benefit from Project activities resulting in certified emission reductions; and

(b) Parties included in Annex 1 may use the certified emissions reductions accruing from such Project activities to contribute to compliance with part of their quantified emission limitation and reduction commitments under Article 3."

The CDM promotes sustainable development and allows developed countries some flexibility due to the fact that they can trade the CERs to meet a part of their emission reduction goals under the 1997 Kyoto Protocol.

The third mechanism is the Emissions Trading, i.e., it has its foundation under Article 17, which authorizes developed countries to have environmental projects designed to reduce emissions.

Titenberg explains that "Emissions trading allows more flexibility in the timing of control investments. Under emissions trading, facilities have the ability to time their expenditures so that they coincide with optimal capital replacement schedules and prevailing market conditions" (Titenberg 2006, pp. 5-6). It can be said that the European Union adopted this mechanism to create the European Union Emissions Trading System (EU ETS).

The central features of the 1997 Kyoto Protocol were the market-based approaches such as the emissions trading and the clean development mechanism. The CDM allows emission reduction projects in developing countries to earn certified emission reduction credits, each equivalent to one tonne of $\mathrm{CO}_{2}$. It is worth mentioning that the European Union (EU) favoured strong targets and limited flexibility, while the United States (US) and other non-EU developed states generally favoured weaker targets and greater flexibility (Bodansky et al. 2017, p. 160).

Currently, Mexico has three different GHG emission reductions mechanisms. The first is the 1997 Kyoto Protocol CDMs regarding CERs in areas such as: biomass energy, coal bed/mine methane, EE industry, EE own generation, fugitive, geothermal, HFCS, hydro, landfill gas, methane avoidance, n20, solar, transport and wind. At the start of CDM implementation, Mexico thus far is hosting 225 projects. Within Latin America, this corresponds to 18\% in CDM projects and 15\% in projects producing CERs (UNEP/CDM, 2020). The second mechanism is a voluntary carbon market in Mexico, where companies can buy Verified Emissions Reductions (VER) or carbon credits. With the 2020 ETS pilot programme, Mexico has the third mechanism for reducing GHG emissions.

The atmosphere as a shared resource is an area of common concern (Birnie et al. 2011, p. 337). Hence, it is crucial to take measures that include all countries worldwide. As widely known, GHG emissions from fossil energy sources contribute to global climate change. This is one of the reasons why emission trading in the 1997 Kyoto Protocol has become an important issue in terms of a global policy to reduce GHG. 
The 2015 Paris Agreement is the most important international instrument worldwide regarding the mitigation of GHG. It was adopted by COP 21 on 12 December 2015 and entered into force on 4 November 2016 (Paris Agreement 2015). This Agreement makes no mention of carbon markets under Articles 6.1 and 6.2, therefore, it allows parties to take voluntary mechanisms in order to implement their nationally determined contributions (NDC) and to use internationally transferred mitigation outcomes to meet its reductions of GHG emissions (Sands et al. 2018, p.324).

Article 6 (4) states that:

"4. A mechanism to contribute to the mitigation of greenhouse gas emissions and support sustainable development is hereby established under the authority and guidance of the Conference of the Parties serving as the meeting of the Parties to this Agreement for use by Parties on a voluntary basis. It shall be supervised by a body designated by the Conference of the Parties serving as the meeting of the Parties to this Agreement, and shall aim:

(a) To promote the mitigation of greenhouse gas emissions while fostering sustainable development;

(b) To incentivize and facilitate participation in the mitigation of greenhouse emissions by public and private entities authorized by a Party;

(c) To contribute to the reduction of emission levels in the host Party, which will benefit from mitigation activities resulting in emission reductions that can also be used by another Party to fulfil its nationally determined contribution; and

(d) To deliver an overall mitigation in global emissions.

This Article promotes the mitigation of GHG through an ETS, supports sustainable development, and involves parties in cooperation. The ultimate purpose of the 2015 Paris Agreement is "to strengthen the global response to the threat of climate change". Regarding long-term mitigation goals, they can be formulated in terms of limiting temperature increase $\left(2{ }^{\circ} \mathrm{C}\right.$ or $1.5^{\circ} \mathrm{C}$ above preindustrial levels); and a GHG emissions reduction goal (50\% by 2050). (Bodansky et al. 2017, p. 228).

According to the Intergovernmental Panel on Climate Change (IPCC) greenhouse gases are:

Those gaseous constituents of the atmosphere, both natural and anthropogenic, which absorb and emit radiation at specific wavelengths within the spectrum of thermal infrared radiation emitted by the Earth's surface, by the atmosphere itself, and by clouds. This property causes the greenhouse effect. Water vapour $(\mathrm{H} 2 \mathrm{O})$, carbon dioxide $(\mathrm{CO} 2)$, nitrous oxide $\left(\mathrm{N}_{2} \mathrm{O}\right)$, methane $(\mathrm{CH} 4)$, and ozone $(\mathrm{O} 3)$ are the primary greenhouse gases in the Earth's atmosphere. Moreover, there are a number of entirely human-made greenhouse gases in the atmosphere, such as the halocarbons and other chlorine- and bromine-containing substances, dealt with under the Montreal Protocol. Besides $\mathrm{CO} 2$, N2O, and $\mathrm{CH} 4$, the Kyoto Protocol deals with the greenhouse gases sulphur hexafluoride (SF6), hydrofluorocarbons (HFCs), and perfluorocarbons (PFCs) (IPCC 2012).

The main GHGs include carbon dioxide $\left(\mathrm{CO}_{2}\right)$, methane $\left(\mathrm{CH}_{4}\right)$, and nitrous oxide $\left(\mathrm{N}_{2} \mathrm{O}\right)$. Some of the GHGs exist in nature and they include water vapour, carbon dioxide, methane, and nitrous oxide; others are exclusively human-made such as fluorinated gases. This is referred to as the enhanced greenhouse effect or 
the anthropogenic greenhouse effect as it is primarily due to human activities (Tan 2014, p. 349).

The international documents mentioned above reaffirm that protecting the environment requires international cooperation. Nevertheless, on 4 November 2019, the United States of America notified the Secretary-General of its decision to withdraw from the 2015 Paris Agreement which shall take effect on 4 November 2020 in accordance with article 28 (1) and (2) of the agreement. This unfortunate decision shows the lack of international cooperation from that country, which is urgently required in order to combat climate change. To this date, 189 Parties of 197 Parties to the Convention have ratified (United Nations, September 2020).

\section{Mexico's NDCs and Other GHG Mitigation Mechanisms in Line with the 2015 Paris Agreement}

Mexico signed the Paris Agreement on 22 April 2016. It was approved by the senate on 14 September 2016 and published on 21 September 2016 in the Official Journal of the Federation (D.O.F.). As a Party of this international instrument, Mexico has amended its 2012 General Law on Climate Change (LGCC) with the aim of harmonizing the law with the objectives established in the Article Two of the Paris Agreement.

Additionally, Mexico has undertaken reforms regarding GHG mitigation with the 2015 Paris Agreement. The 2015 Energy Transition Law (Ley de Transición Energética) was published in D.O.F on 24 December. This law promotes the sustainable and efficient use of energy. According to the law, the Secretariat of Energy (SENER) should promote the generation of clean energy to reach the levels set forth in the LGCC for the electric power industry, including a minimum share of clean energies in electricity generation of $25 \%$ by $2018,30 \%$ by 2021 , and $35 \%$ by 2024 (Article 3 transitory of the 2015 Energy Transition Law). Clean electricity has been set at $5 \%$ for 2018 and the quota will be gradually increased to meet the target of $35 \%$ by 2024 . This energy policy permits the issuance of clean energy certificates (certificados de energia limpia) which aim to promote the generation of clean energy as well as reinforce GHG mitigation. In addition, SENER has recently included the clean energy target of $39.9 \%$ by 2033 and $50 \%$ by 2050 (SENER 2020).

It is worth mentioning that the 1988 General Law on Ecological Balance and Protection of the Environment (LGEEPA) was amended in 2016, 2017, and 2018 with the objective of including the climate change agenda. Following this, the economic instruments to mitigate climate change in Mexico are: (i) the carbon tax, the Climate Change Fund, and the ETS pilot programme.

Furthermore, the 2015 Energy Transition Law also promotes clean energy production. Together with the LGCC, this law could help Mexico to achieve its NDC goals, mitigate the effects of climate change, and produce less $\mathrm{CO}_{2}$ using green energies. 
The Law on Special Tax on Production and Services (Ley del Impuesto especial sobre producción y servicios) was amended in 2012 with the aim of putting a carbon tax applying to $\mathrm{CO}_{2}$ emissions to all sectors covering all fossil fuels, except natural gas (Article 2, I). It is an excise tax, which is capped at $3 \%$ of the fuel sales price. Companies may choose to pay the tax with credits from CDM projects conducted in Mexico or CERs that are also eligible for compliance in the EU ETS, equivalent to the market value of the credits at the time of paying the tax. This carbon price must be paid monthly and the carbon tax is updated yearly (World Bank 2020).

In October 2013, the carbon tax on fossil fuel production was introduced as part of the tax reform package and, in November of the same year, a voluntary carbon exchange, MEXICO2 was established to trade carbon credits. The carbon tax began in January 2014 and the certified emissions reductions can be used to meet $20 \%$ of the carbon tax obligation (IETA 2018).

Climate mitigation goals in Mexico are fivefold: clean energy transition, energy efficiency and sustainable consumption, sustainable cities, reduction of short-lived climate pollutants, sustainable agriculture, and protection of natural carbon sinks.

The 2015 Paris Agreement calls on parties to define an intended nationally determined contribution (INDC). This is a voluntary mechanism, but the key to meeting the Agreement's objectives. This Agreement does not establish specific goals for emissions reductions by parties, which differs from the 1997 Kyoto Protocol (Sands et al. 2018, p. 321). In 2015, Mexico published and submitted to the UNFCCC its commitment to unconditionally reduce " $25 \%$ of greenhouse gases and short-lived climate pollutants emissions (below a Business as usual Baseline, (BAU)) for the year 2030 , i.e., a reduction of $22 \%$ of GHG and a reduction of $51 \%$ of Black Carbon" (INDC 2015).

Mexico's INDC is divided into two parts: (i) mitigation and (ii) adaptation. As for mitigation, Mexico includes two types of measures: unconditional and conditional. The unconditional set of measures are those that Mexico will implement with its own resources, while the conditional actions are those that Mexico could develop if a new multilateral climate regime is adopted and if additional resources and transfer of technology are available through international cooperation.

It is important to mention that Mexico assumes an unconditional international commitment to carry out certain mitigation actions and reaffirms its commitment to combat climate change, to the multilateral rules-based climate regime that requires the participation of all countries, and to sustainable development, as well as its solidarity with the most vulnerable countries.

The Mexican government explained in its INDC that the conditional reductions of $25 \%$ could increase up to $40 \%$ conditionally, subject to a global agreement addressing major topics including international carbon pricing, carbon border adjustments, and technical cooperation. It also includes access to low-cost financial resources and technology transfer, all at a scale commensurate to the challenge of global climate change. Within the same conditions, GHG reductions could increase up to $36 \%$ and Black Carbon reductions to $70 \%$ in 2030 (INDC 2015).

As for unconditional reduction, Mexico is committed to unconditionally reducing $25 \%$ of its GHGs and short-lived climate pollutants emissions (below BAU) for the 
year 2030. This commitment implies a reduction of $22 \%$ of GHG and a reduction of $51 \%$ of Black Carbon" (INDC 2015). "This commitment implies a net emissions peak starting from 2026, decoupling GHG emissions from economic growth: emissions intensity per unit of GDP will reduce by around 40\% from 2013 to 2030. Within the same conditions, GHG reductions could increase up to $36 \%$, and Black Carbon reductions to $70 \%$ in 2030" (INDC 2015).

An achievement for Mexico as of 2015, is the legal mandate for all entities emitting more than 25,000 $\mathrm{tCO}_{2}$ per year to report their emissions of (i) carbon dioxide $\left(\mathrm{CO}_{2}\right)$; (ii) methane (CH4); (iii) nitrous oxide $\left(\mathrm{N}_{2} \mathrm{O}\right)$; (iv) hydrofluorocarbons (HFCs); (v) perfluorocarbons (PFCs); (vi) sulphur hexafluoride (SF6) and; (vii) black carbon in the National Emissions Registry (RENE).

It is worth mentioning that Mexico is a developing country, highly vulnerable to the effects of climate change. National emissions of GHG represent only $1.4 \%$ of global emissions and the net per capita emissions, inclusive of all sectors, are 5.9 $\mathrm{tCO}_{2} \mathrm{e}$ (INDC 2015).

According to the 2018 Global Carbon Atlas, Mexico is in 12th place with 477 MtCOs (Global Carbon Atlas 2018). It is expected that Mexico will be the world's seventh largest economy in 2050 (PWC 2017).

The GHG reduction target for 2020 for Mexico is: (i) $30 \%$ below BAU GHG emission baseline (ambitious); (ii) by 2030: $22 \%$ below BAU GHG emissions baseline, this includes the NDC; and by 2050 below 2000 GHG levels; $50 \%$ included in the LGCC (ambitious).

\section{The Legal Framework of the Pilot Phase of the ETS in Mexico Under the Cap and Trade Principle}

The Mexican 2012 Climate Change Law was amended on 13 July 2018 with the aim of complying with the 2015 Paris Agreement and implementing a national emissions trading system that could help the country meet its mitigation goals. According to Articles 87, 88, 94, and 95 of the LGCC, an Emissions Trade System and a National Emissions Registry will be established with the aim to promote emission reductions in the most cost-efficient way, which is also measurable, reportable, and verifiable.

A regulation to the LGCC regarding the National Emissions Registry (RENE) was published on 28 October 2014, establishing the requirements for reporting GHG emissions (Regulation of the LGCC 28 October 2014). According to Articles 3, 4, 6, and 9 of the Regulation of the LGCC, the energy, transport, industrial, agricultural, residues, commerce, and services sectors are required to report their GHG emissions in the Annual Operational Certificate (Cédula de Operación Anual, COA). The COA is the main bottom-up environmental reporting instrument used by industries to report substances such as air, soil, wastes, pollutants, and GHG emissions.

The adoption of ETS in Mexico in the short and long term is built on the existing monitoring regulations in the National Emissions Registry. It can be said that the 
climate policies in Mexico are directly affected by international regulations and experience due to the fact that the European Union Emission Trading System has been taken into account in the pilot phase of the ETS in Mexico, as established in the second transitory Article of the LGCC, on 13 July 2018. (LGCC, 13 July 2018).

Mexico is currently in the pilot phase (2020-2023) of an Emissions Trading System under the cap and trade principle, with the purpose of reducing carbon dioxide emissions in the energy and industry sectors this phase, whose emissions are greater than 100 thousand direct tonnes of $\mathrm{CO}_{2}$ per year. Around 300 entities are covered representing $\sim 37 \%$ of national emissions (International Carbon Action Partnership, (ICAP 2020a).

It is important to mention that during the pilot phase there is no economic impact on regulated entities. However, in case of non-compliance, the entities will lose the chance to bank unused allowances into the next compliance periods within the pilot phase of the ETS (ICAP 2020a). On 1 October 2019, the rules and terms for the implementation of the ETS in Mexico were published in the Official Journal of the Federation (D.O.F., 1 October 2019).

Regarding the caps for 2020 and 2021, they were published on 27 November 2019 by the Ministry of Environment and Natural Resources (SEMARNAT). Thus, the caps for 2020 are $271.3 \mathrm{MtCO}_{2}$ and for 2021 are $273.1 \mathrm{MtCO}_{2}$ (1) (SEMARNAT, November 27, 2019a). The free allowances allocations for the different sectors were also published by SEMARNAT (SEMARNAT, 27 November 2019b).

As mentioned above, the pilot phase of the ETS is under the cap and trade principle with the purpose of reducing carbon dioxide emissions in the energy and industry sectors, whose emissions are greater than 100 thousand direct tonnes of $\mathrm{CO}_{2}$. This was possible with the support of GIZ (Deutsche Gesellschaft fur internationale Zusammenarbeit $\mathrm{GmbH}){ }^{3}$

It should be noted that an ETS is a market-based instrument, which is used to reduce GHG related to the cap and trade principle. The cap establishes the global limit of GHG, which may be emitted and will be broken down into a number of allowances. These allowances may be traded under the companies regulated by an ETS. The final objective of this is to allow enterprises to comply with their obligations in a cost-efficient manner.

Following this, the Mexican ETS pilot programme started on 1 January 2020 and the scope of the implementation of the ETS includes only $\mathrm{CO}_{2}$ emissions from the energy and industrial sector.

The energy sector includes:

(i) Exploitation;

(ii) Production;

(iii) Transportation and distribution of hydrocarbons; and

(iv) Generation, transmission, and distribution of electricity.

\footnotetext{
${ }^{3}$ The German Federal Ministry for the Environment, Nature Conservation and Nuclear Safety (BMU) has supported the project preparation of an Emissions Trading System in Mexico as a part of the International Climate Initiative.
} 
And from the industrial sector are included:

(i) Automotive;

(ii) Cement;

(iii) Chemical;

(iv) Foods and beverages;

(v) Glass;

(vi) Steel;

(vii) Metallurgical;

(viii) Petrochemical;

(ix) Paper, and so on.

The participants of these sectors will be subject to:

(i) Emissions reporting and verification obligations (taking into account their emissions during the previous year); and

(ii) Obligations related to the delivery of emission rights or allowances (taking into account their emissions during the previous year).

The pilot phase runs from 2020 to 2021 and the transition phase in 2022 constitutes the ETS pilot programme in Mexico. After that, the operational phase will be in place. It covers direct $\mathrm{CO}_{2}$ emissions from entities in the energy and industry sectors, which generate at least $100,000 \mathrm{tCO}_{2}$ per year. Around 300 entities are covered $(37 \%$ of national emissions).

It is important to mention that during the pilot phase, allowances will be free of charge for all the participants and the amount of allowances issued by SEMARNAT and allocated to all of them will be determined based on historical information reported by the National Emissions Registry.

Table 5.1 shows the reserves and the sectoral allocation of allowances for 2020 and 2021 published by SEMARNAT.

As for auctions reserve (5\%), new entrants reserve (10\%), and the general reserve (5\%), they have their foundation under Articles 13, 14, and 15 of the notice of the rules for the establishment of an ETS in Mexico (D.O.F., 1 October 2019).

The implementation of an Emissions Trading System in Mexico is to reduce a cost-effective mitigation measure to achieve its Nationally Determined Contributions of reducing $22 \%$ GHG emissions by 2030 (increasing to $36 \%$, in case of international support and financing) and $50 \%$, by 2050 .

The verified annual $\mathrm{CO}_{2}$ emissions report is made to the National Emissions Register and to the ETS registry. Nevertheless, the 2012 General Law on Climate Change envisages a possible linkage between Mexican ETS and ETS in other countries (LGGC, 13 July 2018, Transitory Article 2). SEMARNAT and the National Institute for Ecology and Climate Change (INECC) are the institutions involved in the establishment and implementation of an ETS. SEMARNAT will review the pilot phase each year and will publish the emission reduction reports supported by INECC. 
Table 5.1 Reserves and sectoral allocation of emissions rights for 2020 and 2021

\begin{tabular}{l|l|l}
\hline & 2020 & 2021 \\
& $\mathrm{MtCO}_{2}$ & $\mathrm{MtCO}_{2}(1)$ \\
\hline CAP & 271.3 & 273.1 \\
\hline Auctions reserve (5\%) & 13.6 & 13.7 \\
\hline New entrants reserve (10\%) & 27.1 & 27.3 \\
\hline General reserve (5\%) & 13.6 & 13.7 \\
\hline Electricity generation & 138.1 & 138.1 \\
\hline Cement & 30.2 & 30.2 \\
\hline Chemical industry & 7 & 7 \\
\hline Glass & 2.7 & 2.7 \\
\hline Iron and steel & 14.7 & 14.7 \\
\hline Lime & 0.6 & 0.6 \\
\hline Mining & 2.1 & 2.1 \\
\hline Oil and gas & 35.5 & 35.5 \\
\hline Refinement & 17.8 & 17.8 \\
\hline Petrochemicals & 5.7 & 5.7 \\
\hline Paper & 2.3 & 2.3 \\
\hline Foods and beverages & 7.7 & 7.7 \\
\hline Others & 7 & 8.8 \\
\hline
\end{tabular}

Source Compiled by author (SEMARNAT, 27 November 2019b)

\section{The European Union Experience in the Emissions Trading System (EU ETS)}

The EU ETS is “a cornerstone of the EU's policy to combat climate change and its key tool for cost-effective reduction of greenhouse gas emissions. It is the world's first major carbon market and remains the biggest" (European Union 2020). It works on the cap and trade principle. It covers $45 \%$ of the EU's greenhouse gas emissions and the main objective is to reduce the cap so that the total emissions fall. The other $55 \%$ comes from emitters such as household, transport users, and agriculture. Thus, the EU ETS is a carbon market operating across 31 countries in the European Union and in the European Economic Area, covering more than 11,000 greenhouse gas emitters including power stations and manufacturing plants, plus some EU flights (CISL 2015).

A cap is set on the total amount of certain GHG that can be emitted by installations covered by the system. Within the cap, companies receive or buy emission allowances, which they can trade with one another as needed. They can also buy limited amounts of international credits from emission-saving projects around the world. The limit on the total number of allowances available ensures that they have a value. After each year, a company must surrender enough allowances to cover all its emissions, otherwise, heavy fines are imposed. If a company reduces its emissions, 
it can keep the spare allowances to cover its future needs or else sell them to another company that is short of allowances. Trading injects flexibility that ensures emissions are cut, where it costs least to do so (ICAP 2020b).

Although the EU ETS created an explicit price on carbon emissions, which reduced emissions by $26 \%$ between 2005 and 2017, this is not enough to combat climate change (Delbeke and Vis 2019, pp. 15-16). Nonetheless, the EU ETS includes a symbolic value, which goes beyond economic consideration and demonstrates the will of the EU to stand as a leader in the international environmental policy context (Borghesi and Montini 2016, p. 3).

Based on the EU ETS experience, Mexico started with monitoring and reporting for the ETS pilot programme with the $\mathrm{CO}_{2}$ emissions only in the energy and industrial sectors. It is worth mentioning that emissions from fixed and mobile sources are also considered.

In the EU ETS, most activities are defined based on a capacity threshold to decide which facility will take part in the ETS. The capacity threshold for combustion activity is expressed by the total rated thermal input and the capacity threshold for industry activities is expressed by production capacity. In the current situation in Mexico, an emission permit is not compulsory. An environmental license called the unique environmental license for the prevention and control of atmospheric pollution is given to the industries.

According to the 2015 report called "10 years of carbon pricing in Europe: a business perspective", published by the Institute for Sustainability leadership of the University of Cambridge, diverse enterprises explained that they made notable progress in reducing their carbon emissions during its lifetime (CISL 2015). Companies saved money through greater efficiency and then got a carbon bonus over their competitors, either by being able to sell allowances or not needing to buy them. The report also shows the flexibility of the EU ETS due to the fact that the benefit of reducing emissions for some is to reduce the amount of allowances they buy, and for others, to leave them with allowances to sell. Mexico has to learn from this flexibility and has to monitor, report, and verify its $\mathrm{CO}_{2}$ emissions every year. The report concluded that the existence of the EU ETS and its reporting requirements has helped companies to focus on carbon. However, companies argue that the carbon price is too low to drive technical innovation.

It is important to mention that there are four trading periods within the EU ETS. The first and the second have concluded, the third is ongoing until 2020, and the fourth has been set up for the years 2021-2030. All of them are governed by the EU ETS Directive 2003/87/EC of the European Parliament and of the Council of 13 October 2003 establishing a scheme for greenhouse gas emission allowance trading within the Community and amending Council Directive 96/61/EC.

The phases of the EU ETS are as follows:

(i) The first phase

The first trading period or phase 1 lasted from the launching of the EU ETS in 2005 until the end of 2007, i.e., 3 years (pilot phase or the pre-Kyoto Period).

(ii) The second phase 
The second trading period or phase 2 began in 2008 and ended in 2012, i.e., 5 years (coinciding with the first commitment period under the 1997 Kyoto Protocol).

Thus, the first and second phase had a free allocation to industry, which was decided on the national level.

(iii) The third phase

In the current third phase or trading period (2013-2020), 8 years, there is no free allocation for electricity production and the free allocation to industry is based on EU harmonized rules outlines in the Benchmarking Decision or Commission Decision of 27 April 2011 determining transitional Union-wide rules for harmonized free allocation of emission allowances pursuant to Article 10a of Directive 2003/87/EC of the European Parliament and of the Council (notified under document C(2011) 2772) (2011/278/EU).

In this third phase, the EU ETS established the centralized registry system (the single European Union Registry).

(iv) The fourth phase

The fourth phase or trading period will start in 2021 and will run until 2030, i.e., 10 years. The aims of the EU ETS are:

(i) to increase the pace of emissions cuts;

(ii) to establish better-targeted carbon leakage framework; and

(iii) to provide funds for low-carbon innovation and energy sector modernization

It is worth mentioning that the EU ETS is the central pillar of the EU Climate Change Policy. Due to the fact that the European Union aims to be climate-neutral by 2050, the Commission will review and propose a revision of climate policy instruments by June 2021 as part of the EU's Green Deal. This includes the EU ETS and a possible extension of emissions trading to new sectors.

The EU ETS applies to $\mathrm{CO}_{2}$ emissions from industry, power, and aviation, and includes industrial processes emissions. It also covers N20 emissions from the certain chemical sector and PFC emissions from primary aluminium production. Mexico applies only to $\mathrm{CO}_{2}$ emissions from the industry and electricity sectors. (ICAP 2020b).

As mentioned above, for the first two trading periods the EU ETS had focussed on $\mathrm{CO}_{2}$ only for the sake of simplicity because it is the main anthropogenic GHG and because of the large monitoring uncertainty in different sectors, as in the waste sector (European Commission 2006). For the third trading period, nitrous oxide $\left(\mathrm{N}_{2} \mathrm{O}\right)$ emissions from fertilizer manufacturing, perfluorocarbon (PFC) emissions from primary aluminium production, and further activities emitting $\mathrm{CO}_{2}$ were introduced.

In order to reduce GHG and to comply with the goals for 2030, the EU has a comprehensive policy which includes, in addition to the EU ETS, the emissions of households, transport users, agriculture and land use, land use change, and forestry (LULUCF). The latter has been added to reach the EU 2030 targets (Delbeke and Vis 2019, p. 17). 


\section{Conclusion}

Mexico's commitment to climate change has been influenced by international agreements such as the 1997 Kyoto Protocol and the 2015 Paris Agreement. The former has put emission trading on the international agenda and the latter has placed emission trading as a new instrument for climate change policy around the world.

Additionally, Mexico has undertaken reforms regarding GHG mitigation in line with the 2015 Paris Agreement. The 2015 Energy Transition Law promotes sustainable and efficient use of energy and SENER has recently included the clean energy target of $39.9 \%$ by 2033 and $50 \%$ by 2050 . The 1988 LGEEPA was amended to include the climate change agenda. The economic instruments for mitigating climate change in Mexico are: (i) the carbon tax, (ii) the Climate Change Fund, and (iii) the ETS pilot programme.

The ETS is a new instrument for environmental protection in Mexico. Therefore, it is very important to gain experience in its implementation during the current pilot phase. However, the effective operation of such a regime requires rules for monitoring, reporting, and verification.

As a developing country, the challenge for Mexico is getting technical and economic support from developed nations. In dealing with climate change, Mexico faces a lot of problems because of its lack of infrastructure, capacity building, transfer of technology, and finance, among others. Therefore, international support in these areas is required.

The EU ETS experience will be taken into account in the pilot phase of ETS (2020-2022) according to the LGCC (36 months). It is expected that at the end of the three phases, Mexico will be able to establish an Emissions Trading System, achieving the emissions reductions not only in the energy and industrial sector, but in other sectors as well. After that time, it is expected that this implementation will be mandatory. The ETS in Mexico will play a key role in promoting decarbonization in sectors such as the energy and industry sectors.

The implementation of an Emission Trading System under the cap and trade principle will help Mexico reach and comply with its INDC goals in the future and combat climate change. One of the benefits of emissions trading is that it provides certainty for environmental outcomes and will foster Mexico's sustainable development.

For Mexico, the implementation of an ETS as a cost-effective mitigation measure to achieve the Nationally Determined Contributions of reducing $22 \%$ GHG emissions by 2030 (increasing to $36 \%$, if it has international support and financing) and $50 \%$ by 2050 is very relevant as a developing country.

The European Union's experience in the Emissions Trading System serves as a good example for implementing the Emissions Trading System in Mexico due to the fact that Mexico has the opportunity to learn and build technology capacities in this matter.

In sum, as a developing country, Mexico needs international support to achieve its targets, including technical, financial, and capacity building. The pilot phase of ETS will help the country to gain experience in this area and collect first experiences 
with auctioning allowances. Moreover, there are many lessons to be learned from the EU ETS, but the most important thing that Mexico has to take into account is that the GHG emissions reductions, clean energy, climate policy, etc., must be done gradually. The learning-by-doing approach of the EU ETS should be implemented in the Mexican climate change policy.

\section{References}

Birnie P, Boyle A, Redgwell C (2009) International law \& the environment, 3rd edn. Oxford University Press, p 358

Bodansky D, Brunnée J, Rajamani L (2017) International climate change law. Oxford University Press, p 228

Borghesi S, Montini M(2016) The best (and worst) of the GHG emission trading systems: comparing the EU ETS with its followers. Front Energy Res 3

CISL (2015) 10 years id Carbon Pricing in Europe, Institute for sustainability leadership, Cambridge University Press

Cassese A (2005) International law, 2nd edn. Oxford University Press, p 487

Commission Decision of 27 April 2011 determining transitional Union-wide rules for harmonized free allocation of emission allowances pursuant to Article 10a of Directive 2003/87/EC of the European Parliament and of the Council (notified under document C (2011) 2772) (2011/278/EU). https://eur-lex.europa.eu/legal-content/EN/TXT/PDF/?uri=CELEX:32011D0278\&from=EN

Delbeke J, Vis P (2019) Towards a climate-neutral Europe: curbing the trend. Routledge. https:// ec.europa.eu/clima/sites/clima/files/toward_climate_neutral_europe_en.pdf

Diario Oficial de la Federación, 01 de octubre de 2019. Acuerdo por el que se establecen las bases preliminares del Programa de Prueba del Sistema de Comercio de Emisiones. Diario Oficial de la Federación, 01.10.2019. https://www.dof.gob.mx/nota_detalle.php?codigo=5573934\&fecha= $01 / 10 / 2019$

Dixon M, McCorquodale R, Williams S (2011) Cases and material son international law, 5th edn, p 441

Directive 2003/87/EC of the European Parliament and of the Council of 13 October 2003 establishing a scheme for greenhouse gas emission allowance trading within the Community and amending Council Directive 96/61/EC. https://eur-lex.europa.eu/legalcontent/EN/TXT/PDF/? uri=CELEX:32003L0087\&from=EN

Dupuy M, Viñuales J (2018) International environmental law, 2nd edn. Cambridge University Press, p 177

European Union (2020) Emission Trading System, climate policies. https://ec.europa.eu/clima/pol icies/ets_en

Global Carbon Atlas (2018) http://www.globalcarbonatlas.org/en/CO2-emissions

IETA (2018) Mexico: a market based climate policy case study. https://www.ieta.org/resources/Res ources/Case_Studies_Worlds_Carbon_Markets/2018/Mexico-Case-Study-Jan2018.pdf

Intended Nationally Determined Contribution, Mexico, March 30, 2015. https://www4.unfccc.int/ sites/submissions/INDC/Published\%20Documents/Mexico/1/MEXICO\%20INDC\%2003.30. 2015.pdf

International Carbon Action Partnership ICAP, ETS Mexico (2020a). https://icapcarbonaction.com/ en/?option=com_etsmap\&task=export\&format=pdf\&layout=list\&systems[]=59

International Carbon Action Partnership ICAP, EU ETS (2020b). https://icapcarbonaction.com/en/? option=com_etsmap\&task $=$ export $\&$ format $=$ pdf \&layout $=$ list \&systems $\% 5 \mathrm{~b} \% 5 \mathrm{~d}=43$

Intergovernmental Panel on Climate Change (IPCC) (2012). Glossary of terms. In: Field CB, Barros V, Stocker TF, Qin D, Dokken DJ, Ebi KL, Mastrandrea MD, Mach KJ, Plattner G-K, Allen SK, Tignor M, Midgley PM (eds) Managing the risks of extreme events and disasters to advance 
climate change adaptation. A Special Report of Working Groups I and II of the Intergovernmental Panel on Climate Change (IPCC). Cambridge University Press, Cambridge, UK, and New York, NY, USA, pp 555-564. https://archive.ipcc.ch/pdf/special-reports/srex/SREX-Annex_Glossary. pdf

Kyoto Protocol to the United Nations Framework Convention on Climate Change (1997). https:// unfccc.int/resource/docs/convkp/kpeng.pdf

Ley General de Cambio Climático, June 6, 2012. http://www.diputados.gob.mx/LeyesBiblio/pdf/ LGCC_130718.pdf

Ley de Transición Energética, December 24, 2015. http://www.diputados.gob.mx/LeyesBiblio/pdf/ LTE.pdf

Malcolm MS (2014) International environmental law, 7th edn. UK, Cambridge University Press, $p$ 617

Paris Agreement (2015) To the United Nations framework convention on Climate Change. https:// unfccc.int/files/essential_background/convention/application/pdf/english_paris_agreement.pdf

PWC (2017) The long view. How will the global economic order change by 2050? February 2017. https://www.pwc.com/gx/en/world-2050/assets/pwc-the-world-in-2050-full-rep ort-feb-2017.pdf

Reglamento de la Ley General de Cambio Climático en materia del Registro Nacional de Emisiones, RENE, 28 de octubre de 2014. http://www.diputados.gob.mx/LeyesBiblio/regley/Reg_LGCC_M RNE_281014.pdf

Reglamento de la Ley de Transición Energética, 04/05/2017. http://www.dof.gob.mx/nota_detalle. php?codigo $=5481526 \&$ fecha $=04 \% 2 \mathrm{~F} 05 \% 2 \mathrm{~F} 2017$

Rio Declaration on Environment and Development to the United Nations framework convention on Environment (1992). https://www.un.org/spanish/esa/sustdev/documents/declaracionrio.htm

Sands P et al (2018) Principles of international environmental law, 4th edn. Cambridge, p 321

SEMARNAT (2019a) AVISO sobre el tope de emisiones del programa del Sistema de Comercio de Emisiones, 27 de noviembre de 2019. https://www.gob.mx/cms/uploads/attachment/file/513 702/Aviso_Tope.pdf

SEMARNAT (2019b) AVISO sobre la asignación sectorial del programa de prueba del Sistema de Comercio de Emisiones, 27 de noviembre de 2019. https://www.gob.mx/cms/uploads/attach ment/file/513701/Aviso_Asignacion_Sectorial.pdf

SENER, Acuerdo por el que la Secretaria de Energia aprueba y publicala actualizacion de la Estrategia de Transición para promover el Uso de Tecnologías y Combustibles más Limpios, en términos de la Ley de Transición Energética, 07/02/2020 http://www.dof.gob.mx/nota_deta lle.php?codigo $=5585823 \&$ fecha $=07 / 02 / 2020$

Tan Z (2014) Air pollution and greenhouse gases, from basic concepts to engineering applications for air emission control. Springer

Titenberg TH (2020) Emissions trading: principles and practice. Washington, DC, Resources for the Future 2006. UNEP DTU CDM/JI Pipeline/CDM projects by host region. https://www.cdm pipeline.org/cdm-projects-region.htm\#top

United Nations Framework Convention on Climate Change (1992). https://unfccc.int/files/essent ial_background/background_publications_htmlpdf/application/pdf/convsp.pdf

United Nations (2020) Treaty collection. https://treaties.un.org/Pages/ViewDetails.aspx?src=TRE ATY\&mtdsg_no=XXVII-7-d\&chapter=27\&clang=_en

World Bank (2020) Carbon pricing dashboard. https://carbonpricingdashboard.worldbank.org/ map_data 
Open Access This chapter is licensed under the terms of the Creative Commons Attribution 4.0 International License (http://creativecommons.org/licenses/by/4.0/), which permits use, sharing, adaptation, distribution and reproduction in any medium or format, as long as you give appropriate credit to the original author(s) and the source, provide a link to the Creative Commons license and indicate if changes were made.

The images or other third party material in this chapter are included in the chapter's Creative Commons license, unless indicated otherwise in a credit line to the material. If material is not included in the chapter's Creative Commons license and your intended use is not permitted by statutory regulation or exceeds the permitted use, you will need to obtain permission directly from the copyright holder.

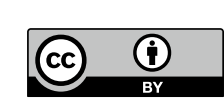

